\title{
Considering Weed Management as a Social Dilemma Bridges Individual and Collective
}

\section{Interests}

Muthukumar V. Bagavathiannan*, Sonia Graham*, Zhao Ma, Jacob N. Barney, Shaun R. Coutts, Ana L. Caicedo, Rosemarie De Clerck-Floate, Natalie M. West, Lior Blank, Alexander L. Metcalf, Myrtille Lacoste, Carlo R. Moreno, Jeffrey Evans, Ian Burke and Hugh Beckie

Muthukumar V. Bagavathiannan, Texas A\&M University, College Station, Texas, USA Sonia Graham, Institut de Ciència y Tecnologia Ambientals, Universitat Autònoma de Barcelona, Spain; School of Social Sciences, University of New South Wales, Australia Zhao Ma, Department of Forestry and Natural Resources, Purdue University, USA Jacob N. Barney, School of Plant and Environmental Sciences, Virginia Tech, Blacksburg, Virginia, USA

Shaun R. Coutts, Animal and Plant Sciences, University of Sheffield, UK

Ana L. Caicedo, University of Massachusetts, Amherst, Massachusetts, USA

Rosemarie De Clerck-Floate, Agriculture and Agri-Food Canada, Lethbridge, Alberta, Canada Natalie M. West, USDA-Agricultural Research Service Pest Management Research Unit, Sidney, Montana, USA

Lior Blank, Department of Plant Pathology and Weed Research, ARO, Volcani Center, Israel Alexander L. Metcalf, W.A. Franke College of Forestry and Conservation, University of Montana, USA

Myrtille Lacoste, Australian Herbicide Resistance Initiative, The University of Western Australia; and Digital Agriculture, Curtin University, Perth, Australia

Carlo R. Moreno, The College of Wooster, Wooster, Ohio, USA Jeffrey Evans, USDA-ARS, Urbana, Illinois; Present address: Farmscape Analytics, Concord, $\mathrm{NH}$, USA

Ian Burke, Washington State University, Pullman, Washington, USA

Hugh Beckie, Agriculture and Agri-Food Canada, Saskatoon, Saskatchewan, Canada; Present address: Director, Australian Herbicide Resistance Initiative, University of Western Australia, Perth, Australia

*Correspondence: Muthukumar Bagavathiannan (muthu@tamu.edu);

Sonia Graham (sonia.graham@unsw.edu.au)

\section{Original article can be found at https://www.nature.com/articles/s41477-019-0395-y}




\section{ABSTRACT}

Weeds pose severe threats to agricultural and natural landscapes worldwide. One major reason for the failure to effectively manage weeds at landscape scales is that current Best Management Practice guidelines, and research on how to improve such guidelines, focus too narrowly on property-level management decisions. Insufficiently considered are the aggregate effects of individual actions to determine landscape-scale outcomes, or whether there are collective practices that would improve weed management outcomes. Here, we frame landscape-scale weed management as a social dilemma, where trade-offs occur between individual and collective interests. We apply a transdisciplinary system approach — integrating the perspectives of ecologists, evolutionary biologists and agronomists into a social science theory of social dilemmas - to four landscape-scale weed management challenges: achieving plant biosecurity, preventing weed seed contamination, maintaining herbicide susceptibility, and sustainably using biological control. We describe how these four challenges exhibit characteristics of "public good problems," wherein effective weed management requires the active contributions of multiple actors, while benefits are not restricted to these contributors. Adequate solutions to address these public good challenges often involve a subset of the eight design principles developed by Elinor Ostrom for "common pool social dilemmas," together with design principles that reflect the public good nature of the problems. This paper is a call to action for scholars and practitioners to broaden our conceptualization and approaches to weed management problems. Such progress begins by evaluating the public good characteristics of specific weed management challenges and applying context-specific design principles to realize successful and sustainable weed management.

Keywords: biological control; common pool resources; herbicide resistance; invasive species; public goods 


\section{Introduction}

Agricultural and environmental weeds constitute a significant ecological, economic, and social problem that impacts natural and managed ecosystems. Weeds threaten global biodiversity ${ }^{1,2}$ when they outcompete native species and impede services provided by the ecosystems they have invaded $^{3,4}$. Weed scientists have developed numerous Best Management Practice (BMP) guidelines to support proactive, integrated strategies. Such BMPs focus on preventing the introduction and spread of weed seeds, improving chemical and biological control, and reducing the risk of resistance evolution to control options, most notably to herbicides ${ }^{5-7}$. Despite these BMPs and the rigorous efforts by researchers and extension personnel who promote them to land managers, weed species continue to spread ${ }^{8}$, and management costs continue to mount as herbicide resistance evolves ${ }^{9}$. We suggest that a major limitation of current BMPs is an underappreciation for the complex, multi-scale, and collective nature of the weed problem ${ }^{10,11}$. We argue that BMPs will be more effective if they are complemented by landscape-scale design principles that encourage cross-boundary coordination and cooperation.

To date, biophysical scientists and resource managers have mostly treated weed issues as ecological or agricultural problems, and social scientists have primarily investigated the intricacies of individuals' weed management decisions. More recently, academics from diverse disciplines have recognized weed management as a "social dilemma”"10,12-15. Broadly defined, social dilemmas are problems for which solutions require the cooperation of many individuals, but the benefits extend to cooperators and non-cooperators alike (i.e., the benefits are nonexcludable). Early social dilemma theories predicted that the long-term collective interests of a society would not accrue because individuals maximize self-interest and tend to free-ride on the efforts of others ${ }^{16}$. Since then, scholars have proven otherwise by documenting numerous examples where cooperation has manifested to produce collective goods ${ }^{17}$, demonstrating the practical value of this line of inquiry. Social theory has advanced to understand the collective nature of certain problems, offering elegant explanations and means for inspiring cooperative behaviour. Here, we review four landscape-scale weed management challenges through the lens of social dilemmas to investigate why current efforts have achieved limited success at large spatial scales, and propose four new design principles to enhance landscape-scale weed management over time. The four challenges focus on preventing the introduction or spread of 
weeds across farms, regions, and nations, and include: (i) plant biosecurity (see footnote $\left.{ }^{1}\right)^{1,18}$, (ii) weed seed contamination $^{19}$, (iii) herbicide susceptibility ${ }^{20}$, and (iv) biological control ${ }^{21}$.

\section{Two broad classes of social dilemmas}

Social scientists have identified two broad classes of social dilemmas: Common Pool Resources (CPRs) and public goods, with distinctions relevant to weed management. To date, much of the natural resource management literature on social dilemmas has focused on CPRs ${ }^{16,22}$. Examples of CPRs include fishing grounds, forests, and irrigation systems ${ }^{23}$. In these cases, the collective resource system is sustained when actors restrain their use of resource units ${ }^{24,25}$. Traditional solutions to CPR problems involve a self-interest model focused on controlling or regulating resource access via a central authority, or through privatizing the resource ${ }^{24,25}$. These solutions are referred to as “demand-side measures”26. Over time, however, scholars have provided substantial evidence of where CPRs have been sustainably managed without adopting the selfinterest model, instead demonstrating how community governance can overcome social dilemmas through reciprocal cooperation ${ }^{25,27}$.

Ostrom $^{22}$ posited eight conditions, or "Design Principles” (DPs), that enabled groups to effectively and sustainably manage landscape-scale common resources. The DPs have been used to implement and evaluate a wide range of CPR solutions, including irrigation, climate change, forest conservation, and fisheries across multiple scales ${ }^{23,28-32}$. Meta-analysis suggests that the presence of each individual DP is significantly correlated with successfully managed CPR systems ${ }^{16}$. Generally, the more DPs met, the more successful CPR governance is likely to be, but there are particular DPs that co-occur in successful CPR endeavours ${ }^{23}$. The original DPs outlined by Ostrom ${ }^{22}$ included:

- DP1: boundaries of both the resource and the user group are clearly defined;

- DP2: rules regarding the appropriation and provision of CPRs are adapted to local needs and conditions;

- DP3: those affected by the rules can participate in modifying the rules;

- DP4: monitoring resource condition and user behavior involves community members;

- DP5: graduated sanctions are in place for rule violators;

1 Biosecurity refers to the protection of countries against alien pests (plants, insects, vertebrates) and diseases ${ }^{18}$. Here we focus on plant biosecurity. 
- DP6: accessible, low-cost means for dispute resolution are available;

- DP7: the rule-making rights of community members are respected by outside authorities; and

- DP8: responsibility for governing the common resource is shared, in nested tiers from the lowest level up to the entire interconnected system.

In natural resource fields, public good dilemmas have received far less attention than CPRs. Indeed, it is often uncritically assumed that governance arrangements for CPRs are applicable to any social dilemma ${ }^{17}$, including public goods ${ }^{16}$. However, public goods have characteristics that suggest only a subset of DPs are likely relevant, and that there may be other principles critical for success, but not yet identified or tested. Public goods require actors to actively contribute toward providing a resource ${ }^{25}$, which is sometimes called "supply-side solutions"26. Examples of public goods include green infrastructure and habitat connectivity, such as wildlife corridors and habitat linkages. The provision of public goods depends on a range of factors ${ }^{33,34}$, including whether: (i) contributions accumulate incrementally or through coordination ${ }^{26}$ (i.e. "additive” vs "joint" contributions); (ii) all actors contribute equally with uniformly distributed benefits or not ${ }^{36}$ (symmetrical vs asymmetrical); (iii) the overall provision is determined by the smallest or largest contributions (i.e. "weakest-link" vs "best-shot") ${ }^{37}$; (iv) provision of public goods requires tiered contributions (first- and second-order) or not ${ }^{34}$; (v) benefits accrue incrementally or if contributions must first surpass some baseline (i.e. threshold aggregator) ${ }^{38}$; and (vi) each contributor's benefits exceed their costs even if many non-contributors benefit ${ }^{38}$.

\section{Weed management as a social dilemma}

The existing weed management literature is inconclusive about whether weed management should be conceptualized as a CPR or public good social dilemma. Few studies specify which theory informed the design and evaluation of weed management approaches. For instance, Ervin and Jussaume ${ }^{39}$ presented herbicide-resistant weeds as a CPR challenge, and suggested that applying most of the CPR governance DPs would help improve management. On the other hand, Ervin and Frisvold ${ }^{11}$ and Coutts et al. ${ }^{10}$ argued that weed control is a weakest-link public good, with Graham $^{40}$ specifying that weed management is an asymmetric, repeated, and additive weakest-link public good. Ervin and Frisvold ${ }^{11}$ as well as Jussaume and Ervin ${ }^{13}$ recognised that issues such as herbicide resistance have characteristics of both CPRs and weakest-link public 
goods. More broadly, Baggio et al. ${ }^{23}$ identified that the number of DPs needed for success may relate to the mobility of the resource and the amount of human investment and effort needed. Thus, conceptual clarity is needed to delineate the CPR and/or public good characteristics of different weed management challenges, as a first step toward facilitating knowledge creation and informing successful practice. A social dilemma approach will help weed management programs link the efforts of individuals on private properties to the broader dynamics of whole systems, which is crucial to enable landscape-scale changes.

Here, we critically examine CPR and public good assertions for weed management at the landscape scale by describing and analyzing the collective nature of four case studies, each representing a major contemporary weed management challenge in agricultural and natural landscapes. In reviewing these case studies we sought to: 1) clarify the extent to which each case exhibits CPR and/or public good characteristics; 2) determine if extant DPs were present or absent; 3) establish which of these DPs were relevant and how they were related to the characteristics of each social dilemma; and 4) identify additional DPs that might enhance proposed solutions. We also discuss context-specific considerations crucial for solving each challenge. As per other research that codes DPs from secondary data ${ }^{16,23}$, we found that some cases had insufficient information to determine if a DP was present or absent and denoted such ambiguities where they occurred (Table 1).

\section{Case study I. Plant biosecurity}

Plant biosecurity - the protection of plant resources from pests-is a key policy and regulatory tool that governments use to limit the intentional or accidental spread of weeds, locally and globally ${ }^{41}$. Plant biosecurity includes quarantine, inspection of freight at ports, and certified treatment schemes such as bulk fumigation of certain types of cargo. We consider plant biosecurity to include state and international efforts, whereas more local and farm-specific efforts constitute a form of weed hygiene with largely distinct players and solutions (see Case study II). Plant biosecurity presents a social dilemma because some governments fail to make the investments necessary to protect global biodiversity, either at transnational (Case study Ia) or sub-national scales (Case study Ib). 
Transnational plant biosecurity. The achievement of an effective transnational plant biosecurity system is defined as a weakest-link public good because routinely addressing new invasive weed threats requires the ongoing efforts (i.e. contributions) of all countries ${ }^{41}$. Success is determined by the level of plant biosecurity provided by the most lax actor (the weakestlink $)^{41}$. It has been shown theoretically ${ }^{42,43}$ and experimentally ${ }^{44}$ that weakest-link characteristics reduce the likelihood of contributions, especially in larger groups.

Achieving transnational plant biosecurity is challenging in part because of these social dynamics, as illustrated by the International Cargo Cooperative Biosecurity Arrangement (ICCBA). The ICCBA was established in 2013 to harmonize treatment of cargo-related biosecurity risks, yet has achieved limited participation and was not designed to maximize collective action. Notably, the ICCBA was made voluntary, with non-binding agreements, and only counted 20 signatories by $2019^{45}$. While the boundaries and actors were clearly defined (DP1) and those who signed the initial agreement were able to negotiate the terms (DP3), there was limited capacity to adapt the rules to local conditions (DP2). Furthermore, no mechanisms were established for monitoring signatory contributions or reductions in biosecurity risks (DP4), sanctioning (DP5), or conflictresolution (DP6). It remains unclear whether the rule-making rights of signatories are being respected by governments who are not signatories (DP7), or whether opportunities for nested governance are employed (DP8). Additionally, the success of the endeavour has been difficult to determine due to a lack of monitoring.

Similar design challenges face other organizational coalitions who work together to produce weed management-related public goods ${ }^{46}$. When organizations cannot monitor and sanction one another, such as in international arrangements like the ICCBA, it becomes imperative that members not only agree to a shared goal, but clearly articulate what their contribution will be and how they will hold themselves accountable. At local levels, there is evidence that the provision of weakest-link weed management-related public goods are more likely to be achieved when members collectively support the weakest-link actor ${ }^{47}$. Thus, ICCBA would benefit from focusing on the weakest-link characteristics of the dilemma to reduce the introduction of weeds through multinational biosecurity collaboration. Support to members with the lowest capacity to contribute could take the form of specifying and reviewing individual contributions, developing 
self-reporting accountability forums, expanding the membership base, or increasing the pool of resources.

Sub-national plant biosecurity. In contrast to international approaches, sub-national plant biosecurity policies allow for more control by individual nations, making it easier to achieve biosecurity governance. For example, Australia is recognised for its concerted biosecurity efforts, including committing significant investments toward achieving biosecurity at subnational scales. In 2012, the Intergovernmental Agreement on Biosecurity established a cooperative partnership among all but one Australian states and territories, signing agreement on a common goal. Consistent with DP1, this involved clearly defined boundaries determining who was required to contribute to the public good of an "effective national biosecurity system"48. While this agreement helped various levels of Australian government jointly identify priority areas, it also capitalized on nested biosecurity systems (DP8). All Australian states and territories have revised or renewed their biosecurity legislation in the past decade (DP2), which is respected by other sub-national and national governments, i.e. external authorities (DP7). The sub-national biosecurity legislation determined who was required to provide, monitor, and enforce biosecurity (DP8), and specified graduated sanctions for those who did not contribute (DP5). Across most states and territories, decisions about which weeds to declare as noxious and corresponding control requirements are determined by local governments ${ }^{49}$. Thus, biosecurity rules are tailored to local conditions (DP2) and individuals affected by the rules are empowered to influence the rules by lobbying their local councils and politicians (DP3). However, courts have been involved when conflicts have arisen, meaning resolution mechanisms are not low-cost (DP6 absent). There is little evidence of consistent monitoring of reductions in plant biosecurity risks, and weed officers who monitor biosecurity at local scales are rarely land managers (DP4 absent), yet past research has shown that weed officers are more likely to be respected when they have longterm ties to the community ${ }^{50}$. While six of the eight DPs are evident in management of the plant biosecurity public good in Australia, and there are strong working relationships among the small number of government actors involved, it is difficult to determine whether these DPs are necessary or sufficient for reducing biosecurity risks because of the lack of monitoring. The lack of monitoring also makes it challenging to identify any particular sub-national actor as the weakest link, and how to effectively support them if needed. 


\section{Case study II. Weed seed contamination}

Weeds, especially close relatives of crops, are common contaminants of crop seeds. For example, weedy rice (Oryza sativa) is a noxious weed that threatens global rice production ${ }^{51}$. Weedy rice grains are more brittle ${ }^{52}$, have different nutritional qualities ${ }^{53}$, and may have red pigmentation that reduces polished rice quality ${ }^{54}$. Due to its propensity for seed shattering and long seed dormancy, weedy rice is an efficient and pernicious invader ${ }^{51,55}$. Season-long weedy rice competition causes up to $80 \%$ yield loss in rice ${ }^{56}$ and can substantially reduce marketable grain quality ${ }^{57}$. Due to the importance of cultivated rice in global diet, weedy rice can adversely affect global food security if not adequately controlled ${ }^{58}$.

Hygienic production BMPs minimize the introduction and spread of weedy rice across fields. They include purchasing and planting certified weed-free rice seeds ${ }^{19}$ and thoroughly cleaning farm machinery and vehicles before moving from one field to another, particularly when shared among farmers ${ }^{59}$. The adoption of hygienic BMPs presents a social dilemma because a weedy rice-free agricultural landscape requires hygienic BMPs by all rice farmers (i.e., contributions). This is an example of an additive public good because it is supplied on a continuous basis ${ }^{60}$. The social dilemma of weedy rice is global in scale ${ }^{51}$, but plays out at regional or local levels.

The benefits of weed hygienic BMPs largely accrue to contributors and non-contributors alike. When one individual achieves weedy-rice-free fields, everyone benefits because propagule pressure is reduced $^{61}$. The more collective resources invested to achieve weedy-rice-free fields, the greater the public benefits: reduced weed management costs, and improved rice yields, grain quality, and profits. Reduced risk of contamination by neighbours’ operations lowers individual weed hygiene costs and increases the quality of seeds, giving farmers access to a greater share of the market and enabling them to receive price premiums ${ }^{62}$.

Uruguay presents a notable example of where stringent weed hygiene measures have been implemented, with about $90 \%$ of rice area planted with certified weed-free seeds ${ }^{63}$. Uruguay has 180,000 ha of irrigated rice production located along the border with Brazil ${ }^{63}$. Boundaries of the public good are clearly defined, as are the people responsible for contributing to it (DP1). In 1997, the National Seed Institute (INASE) was established to encourage the production and use of certified high-quality seed and stimulate the development of the national seed industry (i.e. the 
shared goal $)^{64}$. The national seed industry is a second-order public good that delivers the firstorder public good of a weedy-rice-free agricultural landscape. Rice producers and members of the Seed Users Commission (Comisión de Usarios de Semillas) are on the INASE Board of Directors and are responsible for determining how the organization is run (DP3). INASE sets the rules of how high-quality seed is to be produced, certified, commercialized, exported, and imported (DP2). It determines and applies sanctions for breaking the rules (Ley No 16.811, Uruguay; DP5), while agronomists monitor farmers' fields on a regular basis for any weed seed contamination (DP4) ${ }^{65}$. The provision of high-quality seed is assured through well-established collaborations among producer and research organisations (DP8), who have worked on a range of rice research projects over the past 40 years ${ }^{66}$, and who work together to deliver certified rice seed at affordable prices every year (DP2) ${ }^{67}$. There is insufficient information to determine whether low-cost conflict-resolution mechanisms are in place (DP6 unknown) or whether other government authorities recognise the rights of INASE to organize (DP7 unknown).

Even though creating a weedy-rice-free agricultural landscape is a public good social dilemma, this case study demonstrates that having a shared goal as well as six of the eight DPs created favorable conditions for continuous provisioning of this additive public good, with little adaptation required (Table 1). These conditions have been enabled in Uruguay through additive efforts over the past 75 years to build strong working relationships among farmers, millers, and the government ${ }^{66}$. Beyond the DPs, there is evidence that various actors have committed to, and work together towards, a shared goal with clear expectations of each others' contributions. Transparency in the system ${ }^{65,66}$ offers accountability, not just for the land managers providing the first-order public good (i.e., weedy-rice-free landscape), but also for those who contribute to the second-order public good (i.e., the national seed industry). If the success in Uruguay is to be replicated elsewhere, it seems policy makers should focus on the first five and last DPs, ensure collective goals are shared, and the system is transparent.

\section{Case study III. Herbicide susceptibility}

Herbicide-resistant weed biotypes are proliferating exponentially and threatening farm productivity and profitability ${ }^{68}$; at least 60 countries have reported herbicide-resistant weed biotypes, including more than 400 species-herbicide group combinations ${ }^{69}$. Treating herbicideresistant weeds costs around $\$ 4$ billion annually in the United States (US) alone ${ }^{70}$. The evolution 
and spread of herbicide resistance in Palmer amaranth (Amaranthus palmeri S. Wats.) across the US is an example of a social dilemma pertaining to the maintenance of herbicide susceptibility in an agricultural landscape.

Glyphosate resistance in Palmer amaranth was first confirmed in 2005 in Georgia ${ }^{71}$, and has been subsequently reported in over 25 US states ${ }^{68}$. Multiple resistance (i.e., to more than one herbicide site of action) is also commonly reported in this species across the US (catalogued by Heap ${ }^{68}$ ), a problem analogous to pathogens resistant to multiple antibiotics ${ }^{72}$. The occurrence of herbicideresistant Palmer amaranth has been attributed to a lack of management diversity ${ }^{73}$ and the dispersal of resistant weed propagules across agricultural landscapes ${ }^{74,75}$. In response to widespread herbicide resistance in Palmer amaranth, BMPs have been developed and shared with farmers ${ }^{6,76}$ that were designed to fit local production systems and geared towards managing existing resistance as well as preventing new cases through proactive resistance management. Though adoption has been substantial ${ }^{77}$, BMPs have focused on farm-scale management decisions by individual farmers, rather than collaborative actions at broader community levels.

Weed susceptibility to herbicides has characteristics that reflect CPR as well as public goods $^{11,13,39}$. While herbicide susceptibility can be conceptualised as an exhaustible CPR problem, which requires users to restrain their use pattern of particular herbicides, we argue it has public good characteristics that also need to be recognised. Continued preservation of herbicide susceptibility of weed communities is a public good because it requires all farmers to diversify their management actions (i.e., contributions), which may incur additional expenses and inconvenience in the short-term, but will benefit all farmers in the agricultural landscape over the long-term. Weed species susceptibility to herbicides can be undermined if one farmer repeatedly applies the most economically-attractive or convenient herbicide without implementing diversified weed management strategies. Once weed resistance has evolved on one farm, it can spread rapidly via seed and pollen ${ }^{74,78}$. Thus, susceptibility to herbicides is also a weakest-link public good, and mimics the weed hygiene public good because the spread of herbicide resistance across fields and landscapes can be minimized by improved weed hygiene practices ${ }^{79}$.

Ervin and Frisvold ${ }^{11}$ advocate for a community-based approach to resolve the social dilemma posed by herbicide resistance in weeds. A community-based approach encourages participation of neighboring farms in managing resistance spread ${ }^{80}$. For example, a community-based "zero 
tolerance” program was implemented in the Clay and Crittenden counties of Arkansas to manage Palmer amaranth ${ }^{81}$. This program has rallied farmers, crop consultants, policy makers, and extension personnel around the shared goal of eliminating Palmer amaranth from the region (i.e., a “zero-tolerance” zone). Thus, the program has clearly defined the geographical region of the problem and identified people who can contribute to herbicide susceptibility (DP1). Yet, implementation of the zero-tolerance strategy in a given landscape is voluntary and largely dependent on individual farmers’ willingness to adopt BMPs.

The zero-tolerance program led to a rapid decline in Palmer amaranth seedbank densities within the first few years of program implementation ${ }^{82}$. This occurred despite the lack of rules regarding how herbicide susceptibility should be managed (DPs 2, 3 absent) and a lack of graduated sanctions to punish non-cooperators (DP5 absent), conflict resolution mechanisms (DP6 absent) and monitoring schemes (DP4 absent). There is some evidence that the rights of contributors are recognised by external government authorities (DP7), the county extension agents promoted the program, and nested enterprises such as the Natural Resource Conservation Service were actively involved (DP8) ${ }^{81}$. This suggests that the majority of DPs of CPR governance may not be critical requirements if community and local institutions subscribe to the shared goal. Yet, like other weed management-related public goods, the collective response was enhanced by a forum through which stakeholders could appreciate the cross-boundary nature of the problem, commit to weed control on the diverse land types that they were responsible for, and witness first-hand the benefits of coordinating toward achievable goals ${ }^{46}$.

\section{Case study IV. Weed biological control}

Classical weed biological control (biocontrol) employs host-specific arthropods or pathogens (i.e. agents) from a weed's native environment to reduce weed populations in invaded systems. These strategies typically have high benefit to cost ratios due to long-lasting, low input costs (agents are self-sustaining once established), and provide management options for remote areas or habitats where other tools are unavailable or impractical ${ }^{83-85}$. However, biocontrol agents, as living interacting organisms, can impose irrevocable change to the ecosystem, with pre-release predictions about the efficacy and potential consequences that can only be assessed once the agent is established and widely dispersed. Hence, the deployment of biocontrol as an effective

and environmentally safe weed management tool is hindered by several social challenges. 
Despite the documented success of past programs ${ }^{86,87}$, persistent knowledge gaps and uncertainties about how weed biocontrol agents will behave upon release (e.g., dispersal ${ }^{88}$ and efficacy $^{85,89}$ ) inhibit our ability to accurately delimit physical boundaries for agents on landscapes or adapt rules ahead of their use for weed management (DPs 1, 2 inhibited). The potential for negative ecological impacts can cause conflicts with previously unidentified stakeholders (DPs 1, 3, 6 challenged), particularly with respect to the risks to non-target native plants ${ }^{90,91}$. Finally, the high initial costs of research and development ${ }^{92}$ (i.e., overseas exploration and required host range testing of agents pre-release) can result in an unequal distribution of investments, complicating rule-making, and challenging conflict resolution (DPs 3, 6-8 challenged). Endusers are often unwilling to individually incur the short-term development costs necessary for long-term success of the program. This front-end problem is addressed collectively by establishing funding consortia and leveraging public investments. In these ways, biocontrol resembles an asymmetric public good: there is an imbalance between initial contributors (e.g., public agencies, non-profit research organizations) and those dependent on the outcome (e.g., private and public land managers). Such uneven distributions present significant production challenges that hinge on beneficiaries contributing to development ${ }^{93}$.

The houndstongue (Cynoglossum officinale L.) biocontrol program in western North America provides one example of how asymmetrical public good issues in biocontrol can nevertheless be effectively addressed. In the 1980s, economic impacts by this rangeland weed to the British Columbia (BC) cattle industry led the Canadian government, the BC provincial government, and the BC Cattlemen's Association to establish a consortium that shared front-end costs of a houndstongue biocontrol program ${ }^{94}$. This consortium, which later included stakeholder groups from neighbouring US states, collectively set general program goals and pooled funds to contract an international not-for-profit organization (i.e., the Centre for Agriculture and Biosciences International) to undertake agent exploration and pre-release testing ${ }^{95}$. In 1997, the biocontrol agent Mogulones crucifer Pallas (Curculionidae) was approved for release in Canada and proved highly successful, establishing well at all release sites and significantly reducing weed population densities within two years ${ }^{96}$.

Early successes increased demand for the biocontrol agent, and government research and development investments shifted to its mass-production ${ }^{97}$. Agents were provided first to 
stakeholders who funded the initial development, as well as mass-production research (e.g., cattlemen associations, railway and power companies), thus rewarding those who contributed to the public good. Excess agents were then distributed to private and public land managers in BC and Alberta, Canada, until agents propagated and spread independently ${ }^{95}$, extending benefits beyond initial investors. This is a notable example of a "threshold aggregator" problem where public benefits accrue only after sufficient contributions have been made by early participants.

Although governments initially monitored agent distribution, use, and impact (DP4), this ceased once the agent began dispersing and controlling houndstongue more widely. During the early stages of agent development and use, there were clearly defined contributors and noncontributors (DP1), proportionality was established between those who provided inputs and those who received the benefits (DP2), the right to organise was not challenged by other government authorities (DP7), and nested enterprises were involved in provision of the public good (DP8).

Within the Canadian context, the houndstongue biocontrol program has provided a public good with half of the DPs, although including others may have led to a more efficient or effective process. The use of pooled funds and rewards helped address the asymmetrical aspects of the public good, and the transparent contributions may explain why no graduated sanctions (DP5 absent) or conflict-resolution mechanisms (DP6 absent) were evident. Similar to the herbicide susceptibility case, members of the initial funding consortia shared similar values and needs about rural weed management. However, early involvement of other stakeholders with different values and perspectives pertaining to the weed and its management (e.g., conservation groups concerned about risks to native non-targets), might have facilitated biocontrol development and use, while ensuring more inclusive, broad-based project support as the biocontrol agent continued to spread ${ }^{85}$. In cases where conflicts of interest in the use of biocontrol arise due to differing values, inadequate stakeholder consultations about common goals can significantly delay and increase the costs of a biocontrol program ${ }^{21}$. As such, broader co-design and development are being recognized as important to the continued use of biocontrol ${ }^{83,85}$. Here, application of additional DPs (Table 2) could have contributed a much needed process for developing a more inclusive goal in houndstongue management, while creating greater transparency and awareness of the benefits and risks involved. 
As the houndstongue biocontrol agent spreads across the Canada-US border, additional and ongoing social challenges emerge. Although there are no clearly defined physical boundaries for houndstongue biocontrol (portion of DP1 absent), the political boundary between countries has delayed and complicated the use of the agent as a public good. The US has not given regulatory approval for release of $M$. crucifer on its lands due to potential impacts on a non-target endangered plant closely related to the weed ${ }^{95,98}$. Moreover, the US declared the agent a 'federal pest', legally prohibiting its deliberate movement and use (DP7) ${ }^{99}$, and creating tensions between regulatory agencies upholding non-target protections and those in the US wanting the agent. Currently, there are no low-cost conflict-resolution mechanisms available to manage these tensions (DP6 absent), and US stakeholders have few options for modifying operational rules (i.e., US federal regulations) that could enable them to benefit from the public good (DP3 absent in this situation) ${ }^{100}$. Additional DPs (Table 2) may have also helped in a transnational context by enabling durable cross-border collaboration (e.g., an earlier agreement between the US and Canada to more closely align their regulatory policies on what is an acceptable risk for agent release). However, it is no easy task bridging transnational differences in legislation, politics, or

societal perceptions of biocontrol ${ }^{83,85}$. Future programs could benefit from exploring the DPs as a strategic framework supporting biocontrol from project inception to widespread acceptance and use as a public good.

\section{Conclusion}

Weed management often requires the collective action of myriads of stakeholders, including but not limited to land managers, weed scientists, industry, practitioners, and policy makers. Local circumstances, both natural and socio-political, as well as competing interests among stakeholders, create unique social dilemmas in weed management. The current literature helps guide efforts to study and address some of the most difficult problems in weed management, yet lack of conceptual clarity has limited knowledge creation. Specifically, CPR theory and associated DPs have been applied uncritically and the "public good” nature of weed management has been under-appreciated even in cases where it has high relevance. As highlighted here, achieving plant biosecurity and preventing herbicide resistance both resemble weakest-link public good problems, biocontrol presents asymmetrical public good characteristics, and weed hygiene requires the provision of additive, first- and second-order public goods. 
The public goods view of the specific weed management challenges highlighted here, among many such issues, is compatible with certain DPs laid out for effective and equitable CPR governance by Ostrom ${ }^{22}$. Baggio et al. ${ }^{23}$ previously concluded that DPs 12 2, 4, and 6 were necessary, but not sufficient for successful management of a range of CPRs, and that DPs 5 and 8 were less essential for success. We found that DPs 1, 2, 3, and 8 were the most likely to apply, whereas DPs 4, 5, and 6 were the least important (Table 1) across the four challenges we examined. More often than not, there was little evidence about the presence of DP7, preventing definitive conclusions about its necessity. Critically for DP1, we found that identifying contributors was more important than establishing the boundaries of the public good problem, a significant departure from CPR theory.

Evaluating which DPs are important is challenged by few examples where successes or failures of weed management programs have been monitored or measured. Thus, although monitoring systems were often absent, they are likely a critical condition enabling weed management programs to adapt and facilitating actors to establish new rules as necessary. Even when a monitoring program is in place, assessing success can be a non-trivial task. For example, the number of species moved around the world is growing with increasing trade ${ }^{101}$, but does this represent a failure? Without any biosecurity efforts, the situation could be worse. Having no counterfactual evidence thwarts definitive conclusions. Thus, policy makers should not only consider which DPs are necessary for effective weed management, but also whether there is capacity for other DPs to be useful in future contexts.

Mechanisms for establishing graduated sanctions (DP5) are imperative to enhance collective weed management outcomes in agricultural and natural landscapes ${ }^{102}$. However, such sanctions were absent in three of the cases described above: transnational biosecurity (case Ia), herbicide susceptibility (case III) and biocontrol (case IV) (Table 1). Furthermore, the stringency of enforcement can influence the level of weed management outcomes. Beyond established CPR DPs, we identified four additional principles important to all or some of the cases we examined (Table 2). These included: 1) having a clearly articulated shared goal and securing commitments from actors to contribute; 2) establishing good working relationships and shared values among contributors; 3) making individual contributions transparent; and 4) generating pooled resources to support weakest-link problems or address asymmetries in the public good. These principles 
emphasize the importance of considering whether specific types of weed management have public good characteristics, and the type of public good that applies.

Because public goods require active contributions, shared goals and approaches must respect the unique perspectives and diverse capacities of contributors. Achieving such an agreement requires good working relationships, or at least shared values, where contributors are willing to transparently demonstrate their efforts and contribute shared resources to help those who are least able to contribute. As the additional DPs have been derived from a small set of cases, future research is needed to identify the extent to which these DPs are sufficient or necessary for managing other weed-related public good challenges, the extent to which these DPs are required for diverse types of public goods, and whether there are other public-good specific DPs that require attention.

The novel perspective illustrated here may not be specific to the case studies presented, and considering these dilemmas jointly through a CPR and public good lens highlights the broader social vision required for successful weed management. Engagement processes are needed to encourage, increase, and broaden stakeholder involvement; for instance, platforms supporting evidence-based debates and meaningful participation by those with diverse interests, knowledge, and skill sets ${ }^{103}$. We believe that the approach presented here likely applies to a majority of landscape-scale weed management issues beyond the case-studies described, yet acknowledge that case-specific analyses are imperative for confirming the existence of social dilemmas, application of specific DPs, and a more general identification of suitable strategies for successful weed management.

\section{Correspondence}

Please address all correspondence to Muthukumar Bagavathiannan (ㅆuthu@tamu.edu) and Sonia Graham (onia.graham@unsw.edu.au)

\section{Acknowledgments}

This paper is an outcome of the Third International Workshop on Weeds and Invasive Plants (AnDiNA workshop series), held at Alberta, Canada in June 2016. We acknowledge the sponsorship provided by the Canadian Weed Science Society; the direction provided by Drs. 
Bruce Maxwell, Montana State University and Roger David Cousens, University of Melbourne; and the organizational support provided by Dr. Linda Hall, University of Alberta. We also acknowledge the inputs provided by Drs. Sally Peltzer (Government of Western Australia) and Brian Schutte (New Mexico State University).

\section{Author Contributions}

Project planning, synthesis and writing: MB, SG, ZM, JB, SC, AC, RD, NW, LB, AM, ML, CM, JE, IB and HB. MB and SG contributed equally to the conceptualization and writing of this manuscript.

\section{Competing Interests}

The authors declare no competing interests.

\section{References}

1. Williamson, M. Biological invasions. London, Chapman \& Hall (1996).

2. Parker, I. M. et al. Impact: toward a framework for understanding the ecological effects of invaders. Biol. Inv. 1, 3-19 (1999).

3. Ehrenfeld, J. G. Ecosystem consequences of biological invasions. Annu. Rev. Ecol. Evol. Syst. 41, 59-80 (2010).

4. Pejchar, L. \& Mooney, H. A. Invasive species, ecosystem services and human well-being. Trends Ecol. Evol. 24, 497-504 (2009).

5. DiTomaso, J. M. Invasive weeds in rangelands: species, impacts, and management. Weed Sci. 48, 255-265 (2000).

6. Norsworthy, J. K. et al. (2012) Reducing the risks of herbicide resistance: best management practices and recommendations. Weed Sci. 60, 31-62 (2012).

7. Gill, N., Graham, S., Cross, R. \& Taylor, E. Weed Hygiene Practices in Rural Industries and Public Land Management: Variable Knowledge, Patchy Implementation, Inconsistent Coordination. J. Environ. Manag. 223, 140-149 (2018).

8. Panetta, F. D. Weed eradication feasibility: lessons of the $21^{\text {st }}$ century. Weed Res. 55, 226-238. 
9. Hicks, H. L. et al. The factors driving evolved herbicide resistance at a national scale. Nat. Ecol. Evol. 2, 529-536 (2018).

10. Coutts, S. R., Yokomizo, H. \& Buckley, Y. M. The behaviour of multiple independent managers and ecological traits interact to determine prevalence of weeds. Ecol. Appl. 23, 523536 (2013).

11. Ervin, D. E. \& Frisvold, G. B. Community-based approaches to herbicide-resistant weed management: lessons from science and practice. Weed Sci. 64, 609-626 (2016).

12. Graham, S. A new perspective on the trust-power nexus from rural Australia. J. Rur. Stud. 36, 87-98 (2014).

13. Jussaume, R. A. \& Ervin, D. Understanding weed resistance as a wicked problem to improve weed management decisions. Weed Sci. 64, 559-569 (2016).

14. Gould F., Brown S. Z. \& Kuzma, J. Wicked evolution: can we address the sociobiological dilemma of pesticide resistance? Science 360, 728-732 (2018).

15. Ma, Z., Clarke, M. \& Church, S. Insights into individual and cooperative invasive plant management on family forestlands. Land Use Policy 75, 682-693 (2018).

16. Cox, M., Arnold, G. \& Villamayor Tomás, S. A review of design principles for communitybased natural resource management. Ecol. Soc. 15, 38 (2010).

17. Wilson, D. S., Ostrom, E. \& Cox, M. E. Generalizing the core design principles for the efficacy of groups. J. Econ. Behav. Organi. 90, S21-S32 (2013).

18. Waage, J. K. \& Mumford, J. D. Agricultural biosecurity. Phil. Trans. Roy. Soc. B: Biol. Sci. 363, 863-876 (2008).

19. Delouche, J. C. et al. Weedy rices - origin, biology, ecology and control. Rome. FAO Plant Production and Protection Paper 188. (2007).

20. Frisvold, G. A Social science perspective on weed management practices. In: Proceedings of the National Summit on Strategies to Manage Herbicide-Resistant Weeds. National Research Council. Available: https://www.nap.edu/read/13518/chapter/9 (2012). 
21. Cock, M.J. et al. The impacts of some classical biological control successes. CAB Rev. 10, 158 (2015).

22. Ostrom, E. Governing the Commons: The Evolution of Institutions for Collective Action.

New York, NY: Cambridge University Press (1990).

23. Baggio, J. A. et al. Explaining success and failure in the commons: the configural nature of Ostrom’s institutional design principles. Int. J. Commons 10, 417-439 (2016).

24. Hardin, G. The tragedy of the commons. Science 13, 1243-1248 (1968).

25. Van Vugt, M. \& Snyder, M. Cooperation in society: Fostering community action and civic participation. Am. Behav. Sci. 45, 765-768 (2002).

26. Bisaro, A. \& Hinkel, J. Governance of social dilemmas in climate change adaptation. Nat. Clim.Change 6, 354-359 (2016).

27. Ostrom, E., Burger, J., Field, C. B., Norgaard, R. B. \& Policansky, D. Revisiting the commons: local Lessons, global challenges. Science 284, 278-282 (1999).

28. Araral, E. What explains collective action in the commons? Theory and evidence from the Philippines. World Dev. 37, 687-697 (2009).

29. Dietz, T., Ostrom. E. \& Stern, P. C. The struggle to govern the commons. Science 302, 19071912 (2013).

30. Gutiérrez, N. L., Hilborn, R. \& Defeo, O. Leadership, social capital and incentives promote successful fisheries. Nature 470, 386-389 (2011).

31. Ostrom, E. A general framework for analyzing sustainability of socio-ecological systems. Science 325, 419-422 (2009).

32. Poteete, A. R., Janssen, M. A. \& Ostrom, E. Working together: collective action, the commons, and multiple methods in practice. Princeton, NJ: Princeton University Press (2010).

33. Yamagishi, T. The provision of a sanctioning system as a public good. J. Pers. Soc. Psychol. 51, 110-116 (1986).

34. Heckathorn, D. D. Collective action and the second-order free-rider problem. Rational. Soc. 1, 78-100 (1989). 
35. Walker, J. M. \& Halloran, M. A. Rewards and sanctions and the provision of public goods in one-shot settings. Exp. Econ. 7, 235-247 (2004).

36. Wade-Benzoni, K. A., Tenbrunsel, A. E. \& Bazerman, M. H. Egocentric interpretations of fairness in asymmetric, environmental social dilemmas: Explaining harvesting behavior and the role of communication. Organ. Behav. Hum. Decis. Process. 67, 111-126 (1996).

37. Hirshleifer, J. From weakest-link to best-shot: The voluntary provision of public goods.

Public Choice. 41, 371-386 (1983).

38. Sandler, T. Collective action: fifty years later. Pub. Choice 164, 195-216 (2015).

39. Erwin, D. \& Jussaume, R. Integrating social science into managing herbicide-resistant weeds and associated environmental impacts. Weed Sci. 62, 403-414 (2014).

40. Graham, S. Social relations and natural resource management: the significance of trust and power to solving a collective weed management problem. PhD Thesis. Charles Sturt University, Wagga Wagga (2012).

41. Perrings, C. et al. Biological invasion risks and the public good: An economic perspective. Conserv. Ecol. 6, 1. Available: http://www.consecol.org/vol6/iss1/art1/ (2002).

42. Burnett, K. M. Introductions of invasive species: failure of the weaker link. Agric. Resour. Econ. Rev. 35, 21-28 (2016).

43. Hennessy, D. A. Biosecurity incentives, network effects, and entry of a rapidly spreading pest. Ecol. Econ. 68, 230-239 (2008).

44. Devetag, G. \& Ortmann, A. When and why? A critical survey on coordination failure in the laboratory. Exp. Econ. 10, 331-344 (2007).

45. DAWR. International Cargo Cooperative Agreement. Department of Agriculture and Water Resources. Available: http://www.agriculture.gov.au/biosecurity/partnerships/internationalcargo-cooperative-biosecurity-arrangement (2019).

46. Graham, S., Niemiec, R., Metcalf, A., Gill, N., Moreno, C., Bach, T., Ikutegbe, V., Hallstrom, L., Ma, Z. \& Lubeck, A. Opportunities for better use of collective action theory in 
research and governance for invasive species management. Conserv. Biol. doi:10.1111/cobi.13266 (2019).

47. Graham, S. \& Rogers, S. How local landholder groups collectively manage weeds in southeastern Australia. Environ. Manag. 60, 396-408 (2017).

48. Craik, W., Palmer, D. \& Sheldrake, R. Priorities for Australia’s biosecurity system. An independent review of the capacity of the national biosecurity system and its underpinning intergovernmental agreement. Canberra: Department of Agriculture and Water Resources (2017).

49. Parsons, W. T. \& Cuthbertson, E. G. Noxious weeds of Australia. Collingwood, Australia: CSIRO Publishing (2001).

50. Graham, S. Three cooperative pathways to solving a collective weed management problem. Aust. J. Environ. Manag. 20, 116-129 (2013).

51. Ziska, L. H. Weedy (Red) Rice: An emerging constraint to global rice production. Adv. Agron. 129, 181-228 (2015).

52. Vincenheller, W. G. Rice growing in Arkansas. Ark. Agrl. Exp. Stat. Bull. 89 (1906).

53. Gealy, D. R. \& Bryant, R. J. Seed physicochemical characteristics of field-grown US weedy red rice (Oryza sativa) biotypes: contrasts with commercial cultivars. J. Cereal Sci. 49, 239-245 (2009).

54. Valverde, B. E. The damage by weedy rice - can feral rice remain undetected? Pages 279289 In Crop Ferality and Volunteerism (ed. Gressel). Taylor \& Francis Publishing Group, Boca Raton, Florida, USA (2005).

55. Xia, H. B., Xia, H., Ellstrand, N.C., Yang, C. \& Lu, B. R. Rapid evolutionary divergence and ecotype diversification of germination behavior in weedy rice populations. New Phytol. 191, 1119-1127 (2011).

56. Smith, R. J. Weed thresholds in southern U.S. rice (Oryza sativa). Weed Technol. 2, 232-241 (1988). 
57. Ottis, B. V., Smith, K. L., Scott, R. C. \& Talbert, R. E. (2005) Rice yield and quality as affected by cultivar and red rice (Oryza sativa) density. Weed Sci. 53, 499-504.

58. Nadir, S. et al. Weedy rice in sustainable rice production. A review. Agron. Sustain. Dev. 37, 46 (2017).

59. Singh, K. et al. Weedy rice: an emerging threat for direct-seeded rice production systems in India. J. Rice Res. 1, 106 (2013).

60. Frohlich, N. \& Oppenheimer, J. A. I get by with a little help from my friends. World Politic. 23, 104-120 (1970).

61. Lockwood, J. L., Cassey, P. \& Blackburn, T. The role of propagule pressure in explaining species invasions. Trends Ecol. Evol. 20, 223-228 (2005).

62. El-Azizi, A. F. \& Gomaa, A. A. Certified rice seed production in Egypt in Rice farming systems - New directions. International Rice Research Institute (1989).

63. Pittelkow, C. M. et al. Sustainability of rice intensification in Uruguay from 1993 to 2013. Glob. Food Sec. 9, 10-18 (2016).

64. INASE. National Seed Institute, Uruguay. Available: http://www.inase.uy/Institucional/Instituto.aspx (2018).

65. Zorrilla, G. Uruguay: lessons from a successful rice producer. http://www.ipsnews.net/2012/10/op-ed-uruguay-lessons-from-a-successful-rice-producer/ (2012).

66. Zorrilla, G. Uruguayan rice: the secrets of a success story. Rice Today. 14, 18-19 (2015). 67. Hareau, G. G., Mills, B. F. \& Norton, G. W. The potential benefits of herbicide-resistant transgenic rice in Uruguay: Lessons for small developing countries. Food Policy 31, 162-179 (2006).

68. Heap, I. International Survey of Herbicide Resistant Weeds. Available: http://weedscience.org (2018).

69. Hanson B. D. et al. Herbicide-resistant weeds challenge some signature cropping systems. California Agric. 68, 142-152 (2014). 
70. Smith, P. Herbicide-resistant weeds: what can the U.S. learn from Australia? Available: http://aginfotoday.com/News/HerbicideResistant-Weeds-What-Can-the-US-Learn-FromAustralia-2017-05-22/15959 (2017).

71. Culpepper, S. A. et al. Glyphosate-resistant Palmer amaranth (Amaranthus palmeri) confirmed in Georgia. Weed Sci. 54, 620-626 (2006).

72. Palumbi, S. R. Humans as the world's greatest evolutionary force. Science 293, 1786-1790 (2001).

73. Neve, P., Norsworthy, J. K., Smith, K. L., Zelaya, I. A. Modelling evolution and management of glyphosate resistance in Amaranthus palmeri. Weed Res. 51, 99-112 (2010).

74. Bagavathiannan, M. V., Norsworthy, J. K., Scott, R. C. \& Barber, T. L. The spread of herbicide-resistant weeds: what should growers know? University of Arkansas-Extension Bulletin, FSA-2171. Available: https://www.uaex.edu/publications/pef/FSA-2171.pdf (2013).

75. Bagavathiannan, M. V. \& Norsworthy, J. K. Multiple-herbicide resistance is widespread in roadside Palmer amaranth populations. PLOS ONE 11, e0148748 (2016).

76. Neve, P., Norsworthy, J. K., Smith, K. L. \& Zelaya, I. A. Modeling glyphosate resistance management strategies for Palmer amaranth (Amaranthus palmeri) in cotton. Weed Technol. 25, 335-343 (2011).

77. Schwartz-Lazaro, L. M. et al. 2018. A midsouthern consultant's survey on weed management practices in soybean. Weed Sci. 32, 116-125 (2018).

78. Beckie, H. J., Blackshaw, R. E., Hall, L. M. \& Johnson, E. N. Pollen- and seed-mediated gene flow in kochia (Kochia scoparia). Weed Sci. 64, 624-633 (2016).

79. Michael, P. J., Owen, M. J. \& Powles, S. B. Herbicide-resistant weed seeds contaminate grain sown in the Western Australian grainbelt. Weed Sci. 58, 466-472 (2010).

80. Beckie, H. J. et al. Glyphosate-resistant kochia (Kochia scoparia L. Schrad.) in Saskatchewan and Manitoba. Can. J. Plant Sci. 95, 345-349 (2015).

81. Barber, T. L., Smith, K. L., Scott, R. C., Norsworthy, J. K. \& Vangilder, A. M. Zero tolerance: a community-based program for glyphosate-resistant Palmer amaranth management. 
University of Arkansas-Extension Bulletin, FSA2177. Available:

https://www.uaex.edu/publications/pdf/FSA2177.pdf (2015).

82. Smith, K. L. et al. "Zero Tolerance”: a community-based management program for glyphosate-resistant Palmer amaranth in Arkansas. In: Proceedings of the Weed Science Society of America Annual Meeting, Lexington, Kentucky, 301p (2015).

83. Barratt, B.I.P., Moran, V.C, Bigler, F. \& van Lenteren, J.D. The status of biological control and recommendations for improving uptake for the future. BioControl 63, 155-167 (2018).

84. Paynter, Q., Overton, J. M., Hill, R. L., Bellgard, S. E. \& Dawson, M. I. Plant traits predict the success of weed biocontrol. J. Appl. Ecol. 49, 1140-1148 (2012).

85. Seastedt, T. R. Biological control of invasive plant species: a reassessment for the Anthropocene. New Phytol. 205, 490-502 (2015).

86. Clewey, G. D, Eschen, R., Shaw, R. H. \& Wright, D. J. 2012. The effectiveness of classical biological control of invasive plants. J. Appl. Ecol. 46, 1287-1295 (2012).

87. Winston, R. L. et al. Biological control of weeds: A world catalogue of agents and their target weeds ( $5^{\text {th }}$ ed.) 838 USDA Forest Service, Forest Health Technology Enterprise Team, Morgantown, West Virginia (2014).

88. Paynter, Q. \& Bellgard, S. Understanding dispersal rates of invading weed biocontrol agents. J. Appl. Ecol. 48, 407-414 (2011).

89. Morin, L. et al. Review of approaches to evaluate the effectiveness of weed biological control agents. BioControl. 51, 1-15 (2009).

90. Louda, S. M., Pemberton, R. W., Johnson, M. T. \& Follett, P. Nontarget effects-the Achilles' heel of biological control? Retrospective analyses to reduce risk associated with biocontrol introductions. Ann. Rev. Entomol. 48, 365-396 (2003).

91. Suckling, D. M. \& Sforza, R. F. H. What magnitude are observed non-target impacts from weed biocontrol? PLOS one. 9, e84847 (2014).

92. Paynter, Q., Fowler, S. V., Hayer, L. \& Hill, R. L. Factors affecting the cost of weed biocontrol programs in New Zealand. Biol. Cont. 80, 119-127 (2015). 
93. Warner, K.D. et al. The decline of public interest agricultural science and the dubious future of crop biological control in California. Agric. Human Val. 28, 483-496 (2011).

94. Upadhyaya, M. K. \& Cranston, R. S. Distribution, biology, and control of hound's-tongue in British Columbia. Rangelands 13, 103-106 (1991).

95. De Clerck-Floate, R. A. Cynoglossum officinale (L.), Houndstongue (Boraginaceae) i Biological control programmes in Canada 2001-2012 (eds. Mason, P.G. \& Gillespie, D.) 46, 309-315 CABI Publishing, Wallingford, Oxon, UK. (2013).

96. De Clerck-Floate, R. \& Wikeem, B. Influence of release size on establishment and impact of a root weevil for the biocontrol of houndstongue (Cynoglossum officinale). Biocont. Sci.

Technol. 19, 169-183 (2009).

97. Smith, E. G., De Clerck-Floate, R. A., Van Hezewijk, B. H., Moyer, J. R. \& Pavlik, E. Costs of mass-producing the root weevil, Mogulones cruciger, a biological control agent for houndstongue (Cynoglossum officinale L.). BioControl 48, 281-286 (2009).

98. Catton, H. A., Lalonde, R. G. \& De Clerck-Floate, R. A. Nontarget herbivory by a weed biocontrol insect is limited to spillover, reducing the chance of population-level impacts. Ecol. Appl. 25, 517-530 (2015).

99. USDA-APHIS. Pest Alert: Mogulones cruciger. Animal and Plant Health Inspection Service, United States Department of Agriculture. Plant Prot and Quar (2010).

100. van Klinken, R. D., Morin, L., Sheppard, A. \& Raghu, S. Experts know more than just facts: eliciting functional understanding to help prioritize weed biological control targets. Biol. Inv. 18, 2853-2870 (2016).

101. Seebens, H. et al. No saturation in the accumulation of alien species worldwide. Nat. Comm. 8, 14435 (2017).

102. Hershdorfer M. E., Fernandez-Gimenez, M. E. \& Howery L. D. Key attributes influence the performance of local weed management programs in the southwest United States. Range. Ecol. Manag. 60, 225-234 (2007).

103. Newig, J. \& Fritsch, O. Environmental governance: participatory, multi-level-and effective? Envir. Policy Govern. 19, 197-214 (2009). 
Table 1. Application of Ostrom's Design Principles (DP) of Common Pool Resource (CPR) governance for addressing weed management-related public good governance

\begin{tabular}{|c|c|c|c|c|c|}
\hline \multirow[t]{2}{*}{ Particulars } & \multicolumn{5}{|c|}{ Case study } \\
\hline & $\begin{array}{c}\text { I(a). Trans- } \\
\text { national plant } \\
\text { biosecurity }\end{array}$ & $\begin{array}{c}\text { I(b). Sub- } \\
\text { national plant } \\
\text { biosecurity } \\
\text { (Australia) }\end{array}$ & $\begin{array}{l}\text { II. Weed seed } \\
\text { contami- } \\
\text { nation in } \\
\text { Uruguay }\end{array}$ & $\begin{array}{l}\text { III. Herbicide } \\
\text { susceptibility } \\
\text { in the } \\
\text { Southern USA }\end{array}$ & $\begin{array}{l}\text { IV. Biological } \\
\text { control in } \\
\text { Canada and } \\
\text { across the US } \\
\text { border }\end{array}$ \\
\hline Public Good Characteristics & Weakest-link & Weakest-link & $\begin{array}{l}\text { Additive, first- } \\
\text { and second- } \\
\text { order }\end{array}$ & Weakest-link & Asymmetric \\
\hline \multicolumn{6}{|l|}{ CPR Design Principles* } \\
\hline $\begin{array}{l}\text { DP1: Boundaries of the resource } \\
\text { and the user groups are clearly } \\
\text { defined }\end{array}$ & $\checkmark$ & $\checkmark$ & $\checkmark$ & $\checkmark$ & $\sim$ \\
\hline $\begin{array}{l}\text { DP2: Rules regarding the } \\
\text { appropriation and provision of } \\
\text { CPRs are adapted to local needs } \\
\text { and conditions }\end{array}$ & $\mathrm{x}$ & $\checkmark$ & $\checkmark$ & $\mathrm{x}$ & $\checkmark$ \\
\hline $\begin{array}{l}\text { DP3: Those affected by the rules } \\
\text { can participate in modifying the } \\
\text { rules }\end{array}$ & $\checkmark$ & $\checkmark$ & $\checkmark$ & $\mathrm{X}$ & $\sim$ \\
\hline $\begin{array}{l}\text { DP4: Monitoring of resource } \\
\text { condition and user behavior } \\
\text { involves community members }\end{array}$ & $\mathrm{x}$ & $\mathrm{x}$ & $\checkmark$ & $\mathrm{x}$ & $\sim$ \\
\hline $\begin{array}{l}\text { DP5: Graduated sanctions are in } \\
\text { place for rule violators }\end{array}$ & $\mathrm{x}$ & $\checkmark$ & $\checkmark$ & $\mathrm{x}$ & $\mathrm{X}$ \\
\hline $\begin{array}{l}\text { DP6: Accessible, low-cost means } \\
\text { for dispute resolution are } \\
\text { available }\end{array}$ & $\mathrm{x}$ & $\mathrm{x}$ & & $\mathrm{X}$ & $\mathrm{X}$ \\
\hline $\begin{array}{l}\text { DP7: The rule-making rights of } \\
\text { community members are } \\
\text { respected by outside authorities }\end{array}$ & & $\checkmark$ & & & \\
\hline $\begin{array}{l}\text { DP8: Responsibility for } \\
\text { governing the common resource is } \\
\text { shared in nested tiers from the } \\
\text { lowest level up to the entire } \\
\text { interconnected system }\end{array}$ & & $\checkmark$ & $\checkmark$ & & $\checkmark$ \\
\hline
\end{tabular}

*Green cells $(\checkmark)$ indicate that there is evidence that the DP applies for the specific case study; orange cells (x) indicate that there is evidence that the DP does not apply; blue cells $(\sim)$ indicate that only part of the DP applies; and grey cells (no symbols) indicate that there is insufficient information about whether or not the specific DP applies. 
Table 2. Additional Design Principles (DP) relevant to addressing weed management-related public good governance*

\begin{tabular}{|l|c|c|c|c|c|}
\hline Particulars & \multicolumn{3}{|c|}{ Case study } \\
\hline & $\begin{array}{c}\text { I(a). Trans- } \\
\text { national } \\
\text { plant } \\
\text { biosecurity } \\
\text { I(b). Sub- } \\
\text { national } \\
\text { plant } \\
\text { biosecurity } \\
\text { (Australia) }\end{array}$ & $\begin{array}{c}\text { II. Weed } \\
\text { seed } \\
\text { contami- } \\
\text { nation in } \\
\text { Uruguay }\end{array}$ & $\begin{array}{c}\text { III. Herbicide } \\
\text { susceptibility in } \\
\text { the Southern } \\
\text { USA }\end{array}$ & $\begin{array}{c}\text { IV. Biological } \\
\text { control in } \\
\text { Canada and } \\
\text { across the US } \\
\text { border }\end{array}$ \\
\hline $\begin{array}{l}\text { Contributors agree to a } \\
\text { shared goal }\end{array}$ & $\checkmark$ & $\checkmark$ & $\checkmark$ & $\checkmark$ & $\checkmark$ \\
\hline $\begin{array}{l}\text { Contributions are } \\
\text { made transparently }\end{array}$ & $\checkmark$ & $\checkmark$ & & $\checkmark$ \\
\hline $\begin{array}{l}\text { Contributors pool } \\
\text { resources to support } \\
\text { weakest-links or } \\
\text { address asymmetries } \\
\text { in the public good }\end{array}$ & & & & & \\
\hline $\begin{array}{l}\text { Strong working } \\
\text { relationships or shared } \\
\text { values among } \\
\text { contributors }\end{array}$ & & $\checkmark$ & & $\checkmark$ & $\checkmark$ \\
\hline
\end{tabular}

*Green cells $(\checkmark)$ indicate that there is evidence that the DP applies for the specific case study; and grey cells (no symbols) indicate that there is insufficient information about whether or not the specific DP applies. 